\title{
The effects of etomidate and midazolam on adipose tissue- derived mesenchymal stem cell proliferation
}

\author{
Ho Park ${ }^{1}$, Kyoungho Ryu ${ }^{2}$, Yun-Hong Kim², Won-Jun $\mathrm{Choi}^{2}$, and \\ Dongchan $\mathrm{Ko}^{2}$ \\ ${ }^{I}$ Department of Clinical Laboratory Science, Wonkwang Health Science University, Iksan, ${ }^{2}$ Department of \\ Anesthesiology and Pain Medicine, Kangbuk Samsung Hospital, Sungkyunkwan University School of Medicine, \\ Seoul, Korea
}

\begin{abstract}
Background: Stem cell therapy using adipose tissue-derived mesenchymal stem cells (ADSCs), which are capable of multipotent differentiation, is currently being investigated in the field of tissue regeneration and the treatment of patients in intensive care units. It is known that type-A $\gamma$-aminobutyric acid $\left(\mathrm{GABA}_{\mathrm{A}}\right)$ receptor activity has an influence on stem cell proliferation. Thus, we investigated the effects of the clinically available $\mathrm{GABA}_{\mathrm{A}}$ receptor agonists, etomidate and midazolam, on ADSC proliferation measured by the cell counting kit-8 assay.

Methods: ADSCs cultured in control medium or adipogenic differentiation medium for 15 days were divided into 5 treatment groups: non-medicated (Control) and 4 groups including treatment with etomidate or midazolam at 1 and 50 $\mu \mathrm{M}$ ( $\mathrm{n}=3$ per group). The cell counting kit- 8 assay was performed for determining the cell proliferation in both medium groups at day $0,3,6,9,12$, and 15 in culture. The absorbance values at $450 \mathrm{~nm}$ were then measured by enzyme-linked immunosorbent assay reader and statistically compared among groups.

Results: There was no significant difference in cell proliferation profiles among the 5 groups at any time point in both control and adipogenic differentiation media.

Conclusions: Etomidate and midazolam did not influence ADSC proliferation under both media when compared to the non-medicated group and there was no dose-dependent effect of etomidate and midazolam on ADSC viability.
\end{abstract}

Key Words: Cell proliferation, Etomidate, GABA receptor, Mesenchymal stromal cells, Midazolam.

Corresponding author: Kyoungho Ryu, M.D.

Department of Anesthesiology and Pain Medicine, Kangbuk Samsung Hospital, Sungkyunkwan University School of Medicine, 29, Saemunanro, Jongno-gu, Seoul 03181, Korea

Tel: 82-2-2001-1376, Fax: 82-2-2001-2326

Email: drkhryu@gmail.com

ORCID: http://orcid.org/0000-0002-2886-1836

It was presented The 92th Annual Scientific Meeting of the Korean Society of Anesthesiologists, November 2015, Bexco, Busan, Korea.

Received: November 25, 2015.

Revised: March 14, 2016 (1st); May 25, 2016 (2nd).

Accepted: July 7, 2016.

Korean J Anesthesiol 2016 December 69(6): 614-618

https://doi.org/10.4097/kjae.2016.69.6.614

\section{Introduction}

Mesenchymal stem cells (MSCs), a type of adult stem cells, are distributed in various tissues and are capable of multipotent differentiation into osteogenic, chondrogenic, and adipogenic cell lineages [1]. It is acknowledged that a population of MSCs is isolated from adult human adipose tissues, which can be harvested in large amounts by liposuction [2]. In recent years, clinical trials with adipose tissue-derived MSCs (ADSCs) are being attempted. To achieve improved fat-graft survival, ADSC basedtissue engineering and regeneration are recently co-introduced in the surgical fields where autologous fat grafts alone have been in charge [3-6]. Recent studies have also investigated whether

(c) This is an open-access article distributed under the terms of the Creative Commons Attribution Non-Commercial License (http://creativecommons.org/ licenses/by-nc/4.0/), which permits unrestricted non-commercial use, distribution, and reproduction in any medium, provided the original work is properly cited. 
stem cell therapy with ADSCs can be used for improving the outcome of patients in intensive care units, including the acute urogenital organ damage observed in sepsis [7] and toxic shock syndrome [8]. Several factors should be considered to achieve successful stem cell therapy [9]. Among these, maintaining the applied stem cells at an active proliferation state, or the maintenance of cell viability, is essential to achieve stem cell therapy objectives.

Previous studies raise the possibility that the type-A $\gamma$-aminobutyric acid $\left(\mathrm{GABA}_{\mathrm{A}}\right)$ receptor is involved in modulating stem cell proliferation $[10,11]$. Currently, well-known intravenous $\mathrm{GABA}_{\mathrm{A}}$ receptor agonists, etomidate, and midazolam, are used for sedation of patients in surgery or in intensive care units. They act through the enhancement of GABA mediated inhibition via the synaptic $\mathrm{GABA}_{\mathrm{A}}$ receptor $[12,13]$.

However, the effect of clinically available GABAergic agents on ADSC proliferation is not known. Thus, our study investigated the effects of the clinically available GABAergic agents, etomidate and midazolam, on ADSC proliferation both in control medium and under induction of adipogenic differentiation using the Cell Counting Kit-8 (CCK-8) assay.

\section{Materials and Methods}

\section{Isolation and preparation of ADSCs}

Ethical approval for this study protocol was obtained from the Institutional Review Board of Kangbuk Samsung Hospital (IRB File No: 2011-01-031). The ADSCs used in this study were obtained from the lipoaspirates of donors after receiving informed consent, using a previously reported method $[14,15]$. In brief, the lipoaspirates were washed extensively with sterile Dulbecco's phosphate buffered saline (DPBS) (Biowest, Rue de la Caille, Nuaillé, France) to remove the contaminating debris and blood cells. The rinsed aspirates were treated with $0.075 \%$ collagenase type I in DPBS for $60 \mathrm{~min}$ at $37^{\circ} \mathrm{C}$ under gentle agitation and then inactivated with an equal volume of Dulbecco's modified Eagle's medium (DMEM) (Gibco, Grand Island, NY, USA)/ 10\% fetal bovine serum (FBS) (Gibco, Grand Island, NY, USA). The cell pellet collected by low speed centrifugation for 10 min was resuspended in DMEM containing 10\% FBS and strained through a $100-\mu \mathrm{m}$ mesh filter to remove debris. After centrifugation as detailed above, the filtrate was plated onto conventional tissue culture plates in control medium (DMEM, 10\% FBS, $1 \%$ antibiotic/antimycotic solution [Gibco, Grand Island, NY, USA]) and incubated at $37^{\circ} \mathrm{C}$ in a $\mathrm{CO}_{2}$ incubator. The control medium was replaced with fresh medium after every 3 days. During the study period, ADSCs were maintained at a density of $8 \times 10^{4}$ cells per well in a 6-well plate in the control medium. The ADSCs for this study were from passages 3-5.

\section{Induction of Adipogenic differentiation in ADSCs}

ADSCs were incubated at a density of $8 \times 10^{4}$ cells per well in a 6-well plate in complete medium for $24 \mathrm{~h}$ at $37^{\circ} \mathrm{C}$ in a $\mathrm{CO}_{2}$ incubator. After confirming cell adhesion, ADSCs were cultured with adipogenic differentiation medium comprising $1 \mu \mathrm{M}$ dexamethasone (Sigma, St. Louis, MO, USA), $1 \mu \mathrm{M}$ indomethacin (Sigma, St. Louis, MO, USA), $500 \mu \mathrm{M}$ 3-isobutyl-1-methylzanthine (Sigma, St. Louis, MO, USA), and $10 \mu \mathrm{g} / \mathrm{ml}$ insulin (Sigma, St. Louis, MO, USA) in complete medium [16]. Cell differentiation was induced for 15 days with media replacement once in every 3 days.

\section{Cell treatment with GABAergic anesthetics}

The ADSCs under control or adipogenic differentiation medium were divided into the non-medicated group and 4 experimental groups based on the type and amount of GABAergic agents applied to the cells ( $n=3$ for each group). ADSCs cultured in control or differentiation medium were simultaneously treated with GABAergic anesthetics. During medium changes, the prepared etomidate (Lipuro ${ }^{\circledR} 2 \%$ inj, B. Braun, Melsungen, Germany) or midazolam (Midazolam ${ }^{\circledR} 1 \%$ inj, Bukwang pharmaceutical. Co. Ltd., Ansan, Korea) was added to the cultured ADSCs to achieve final concentrations of 1 and $50 \mu \mathrm{M}$. The concentration of each agent was determined based on previous references; the optimal plasma concentrations of each agent for sedation were $1 \mu \mathrm{M}$ for etomidate and $1 \mu \mathrm{M}$ for midazolam [17], and the concentration of etomidate and midazolam resulting in declined cardiac performance was beyond $50 \mu \mathrm{M}$ [18].

\section{Determination of proliferative ability of ADSCs}

The CCK-8 assay allows sensitive colorimetric determination of cell viability in cell proliferation and cytotoxicity assays. A highly water-soluble tetrazolium salt, WST-8 [2-(2-methoxy4-nitrophenyl)-3-(4-nitrophenyl)-5-(2,4-disulfophenyl)-2Htetrazolium, monosodium salt], is reduced by the dehydrogenase activity in cells to generate a yellow-colored formazan dye, which is soluble in tissue culture media. The amount of the formazan dye, generated by the dehydrogenase activity in cells, is directly proportional to the number of living cells. The assay was conducted in ADSCs at $0,3,6,9,12$, and 15 days after induction of cell proliferation or adipogenic differentiation according to the manufacturer's instructions. In brief, ADSCs cultured in a 6-well plated were washed with PBS and then incubated in the dark with a mixture of control medium and the CCK-8 reagent at a ratio of $20: 1$. After $90 \mathrm{~min}$ at $37^{\circ} \mathrm{C}$ in a $5 \%$ $\mathrm{CO}_{2}$ incubator, the cells were analyzed using an enzyme-linked immunosorbent assay (ELISA) reader with the wavelength set 
to $450 \mathrm{~nm}$. The absorbance values from the ELISA reader were used to determine the degree of cellular proliferation.

\section{Statistical analysis}

To prove whether cell viability values measured by the CCK- 8 assay at each time point showed normal distribution, the Kolmogorov-Smirnov test was performed. Since the data showed non-normal distribution at some measured time points, the Kruskal Wallis test was used to compare the data among 5 comparison groups.

Statistical significances were determined after Bonferroni's method to adjust type I error. The data were analyzed using PASW Statistics 18.0 (SPSS Inc., Chicago, IL, USA). Values of P $<0.05$ were considered statistically significant.

\section{Results}

Values obtained from the CCK-8 assay are presented as median (Q1-Q3) (Tables 1 and 2). According to the KolmogorovSmirnov test, the results of the CCK-8 assay were not normally distributed at day 12 and 15 in control media (both $\mathrm{P}<0.001$ ), and at day 6 and 9 in adipogenic differentiation media $(\mathrm{P}<0.001$ and $\mathrm{P}=0.001$, respectively). Thus, because the data were not normally distributed, the statistical analyses were performed using Kruskal-Wallis test to investigate the differences in cell proliferation among groups.

In the control medium, no statistical difference in cell viability was observed at $0,3,6,9,12$, and 15 days among the control group and the midazolam and etomidate groups with a dose for sedation, at $1 \mu \mathrm{M}$, and a high dose for suppression of cardiac function, at $50 \mu \mathrm{M}$ (Table 1). Even under adipogenic dif-

Table 1. Results of the CCK-8 Assay for Adipose Derived Mesenchymal Stem Cells in Control Medium

\begin{tabular}{|c|c|c|c|c|c|c|}
\hline & $\begin{array}{l}\text { No medication } \\
(\text { Control }) \\
(\mathrm{n}=3)\end{array}$ & $\begin{array}{c}\text { Etomidate } \\
1 \mu \mathrm{M} \\
(\mathrm{n}=3)\end{array}$ & $\begin{array}{l}\text { Etomidate } \\
50 \mu \mathrm{M} \\
(\mathrm{n}=3)\end{array}$ & $\begin{array}{c}\text { Midazolam } \\
1 \mu \mathrm{M} \\
(\mathrm{n}=3)\end{array}$ & $\begin{array}{l}\text { Midazolam } \\
50 \mu \mathrm{M} \\
(\mathrm{n}=3)\end{array}$ & $P$ value \\
\hline Day 0 & $\begin{array}{c}0.439 \\
(0.436,0.441)\end{array}$ & $\begin{array}{c}0.447 \\
(0.445,0.447)\end{array}$ & $\begin{array}{c}0.422 \\
(0.422,0.427)\end{array}$ & $\begin{array}{c}0.415 \\
(0.409,0.422)\end{array}$ & $\begin{array}{c}0.427 \\
(0.393,0.430)\end{array}$ & 0.186 \\
\hline Day 3 & $\begin{array}{c}0.475 \\
(0.467,0.476)\end{array}$ & $\begin{array}{c}0.470 \\
(0.414,0.472)\end{array}$ & $\begin{array}{c}0.431 \\
(0.427,0.433)\end{array}$ & $\begin{array}{c}0.399 \\
(0.395,0.400)\end{array}$ & $\begin{array}{c}0.417 \\
(0.409,0.421)\end{array}$ & 0.462 \\
\hline Day 6 & $\begin{array}{c}0.557 \\
(0.546,0.559)\end{array}$ & $\begin{array}{c}0.580 \\
(0.579,0.582)\end{array}$ & $\begin{array}{c}0.571 \\
(0.548,0.572)\end{array}$ & $\begin{array}{c}0.525 \\
(0.484,0.527)\end{array}$ & $\begin{array}{c}0.509 \\
(0.502,0.514)\end{array}$ & 0.144 \\
\hline Day 9 & $\begin{array}{c}0.713 \\
(0.699,0.730)\end{array}$ & $\begin{array}{c}0.627 \\
(0.620,0.689)\end{array}$ & $\begin{array}{c}0.688 \\
(0.681,0.689)\end{array}$ & $\begin{array}{c}0.585 \\
(0.576,0.589)\end{array}$ & $\begin{array}{c}0.504 \\
(0.491,0.510)\end{array}$ & 0.066 \\
\hline Day 12 & $\begin{array}{c}0.911 \\
(0.910,0.916)\end{array}$ & $\begin{array}{c}0.907 \\
(0.907,0.916)\end{array}$ & $\begin{array}{c}0.901 \\
(0.900,0.906)\end{array}$ & $\begin{array}{c}0.820 \\
(0.819,0.822)\end{array}$ & $\begin{array}{c}0.729 \\
(0.728,0.736)\end{array}$ & 0.120 \\
\hline Day 15 & $\begin{array}{c}1.038 \\
(1.027,1.044)\end{array}$ & $\begin{array}{c}0.817 \\
(0.806,0.825)\end{array}$ & $\begin{array}{c}0.784 \\
(0.781,0.788)\end{array}$ & $\begin{array}{c}0.829 \\
(0.829,0.833)\end{array}$ & $\begin{array}{c}0.757 \\
(0.755,0.761)\end{array}$ & 0.066 \\
\hline
\end{tabular}

Values are presented as median (Q1-Q3).

Table 2. Results of the CCK-8 Assay for Adipose Derived Mesenchymal Stem Cells in Adipogenic Differentiation Medium

\begin{tabular}{|c|c|c|c|c|c|c|}
\hline & $\begin{array}{l}\text { No medication } \\
\quad(\text { Control }) \\
(\mathrm{n}=3)\end{array}$ & $\begin{array}{c}\text { Etomidate } \\
\qquad 1 \mu \mathrm{M} \\
(\mathrm{n}=3)\end{array}$ & $\begin{array}{l}\text { Etomidate } \\
\begin{array}{l}50 \mu \mathrm{M} \\
(\mathrm{n}=3)\end{array}\end{array}$ & $\begin{array}{c}\text { Midazolam } \\
1 \mu \mathrm{M} \\
(\mathrm{n}=3)\end{array}$ & $\begin{array}{l}\text { Midazolam } \\
50 \mu \mathrm{M} \\
(\mathrm{n}=3)\end{array}$ & $P$ value \\
\hline Day 0 & $\begin{array}{c}0.576 \\
(0.487,0.577)\end{array}$ & $\begin{array}{c}0.484 \\
(0.460,0.496)\end{array}$ & $\begin{array}{c}0.484 \\
(0.477,0.505)\end{array}$ & $\begin{array}{c}0.514 \\
(0.495,0.515)\end{array}$ & $\begin{array}{c}0.447 \\
(0.431,0.466)\end{array}$ & $>0.999$ \\
\hline Day 3 & $\begin{array}{c}0.494 \\
(0.494,0.497)\end{array}$ & $\begin{array}{c}0.494 \\
(0.491,0.496)\end{array}$ & $\begin{array}{c}0.446 \\
(0.445,0.449)\end{array}$ & $\begin{array}{c}0.493 \\
(0.488,0.494)\end{array}$ & $\begin{array}{c}0.476 \\
(0.474,0.477)\end{array}$ & 0.132 \\
\hline Day 6 & $\begin{array}{c}0.920 \\
(0.903,0.926)\end{array}$ & $\begin{array}{c}0.636 \\
(0.634,0.640)\end{array}$ & $\begin{array}{c}0.643 \\
(0.642,0.648)\end{array}$ & $\begin{array}{c}0.637 \\
(0.636,0.641)\end{array}$ & $\begin{array}{c}0.625 \\
(0.623,0.629)\end{array}$ & 0.144 \\
\hline Day 9 & $\begin{array}{c}1.112 \\
(1.088,1.114)\end{array}$ & $\begin{array}{c}1.164 \\
(1.146,1.179)\end{array}$ & $\begin{array}{c}1.236 \\
(1.202,1.250)\end{array}$ & $\begin{array}{c}1.117 \\
(1.114,1.130)\end{array}$ & $\begin{array}{c}0.855 \\
(0.836,0.874)\end{array}$ & 0.090 \\
\hline Day 12 & $\begin{array}{c}1.207 \\
(1.195,1.218)\end{array}$ & $\begin{array}{c}0.856 \\
(0.832,0.865)\end{array}$ & $\begin{array}{c}0.915 \\
(0.914,0.924)\end{array}$ & $\begin{array}{c}0.911 \\
(0.909,0.916)\end{array}$ & $\begin{array}{c}0.505 \\
(0.498,0.508)\end{array}$ & 0.066 \\
\hline Day 15 & $\begin{array}{c}0.654 \\
(0.650,0.662)\end{array}$ & $\begin{array}{c}0.570 \\
(0.569,0.573)\end{array}$ & $\begin{array}{c}0.626 \\
(0.587,0.629)\end{array}$ & $\begin{array}{c}0.686 \\
(0.682,0.689)\end{array}$ & $\begin{array}{c}0.435 \\
(0.430,0.436)\end{array}$ & 0.072 \\
\hline
\end{tabular}

Values are presented as median (Q1-Q3). 
ferentiation medium, the dehydrogenase activities of viable cells measured by the CCK- 8 assay were not statistically different at any of the time points among the control and medication groups (Table 2).

\section{Discussion}

The present study revealed that the clinically available $\mathrm{GABA}_{\mathrm{A}}$ receptor agonists, etomidate and midazolam, did not influence the proliferation of ADSC when compared to that in the nonmedicated group.

In the field of stem cell biology, it is known that $\mathrm{GABA}_{\mathrm{A}}$ receptor is expressed not only in neural stem cells [19], but also in different types of extraneural stem cells in the undifferentiated proliferative state $[10,20]$. As observed with embryonic stem cells [10], the $\mathrm{GABA}_{\mathrm{A}}$ receptor, which is a binding site for etomidate or midazolam, is also expressed in human ADSCs [21]. However, the $\mathrm{GABA}_{\mathrm{A}}$ receptor subunit composition in ADSCs is not yet reported, even though Andang et al. [10] reported that embryonic stem cells express the GABA $A_{A}$ receptor subunits $\alpha_{1}$, $\alpha_{3-5}, \beta_{3}, \varepsilon, \pi$, and $\theta$; they did not examine the $\rho$ subunits.

Moreover, $\mathrm{GABA}_{\mathrm{A}}$ receptor is involved in modulating the cell cycle, especially DNA synthesis [10,22], and the activity of the $\mathrm{GABA}_{\mathrm{A}}$ receptor on stem cells or on progenitor cells has an influence on cell proliferation [10,11]. Additionally, GABA along with the activating $\mathrm{GABA}_{\mathrm{A}}$ receptor is known as a cell-cycle regulator [22,23]. Previous studies like these raised the possibility that clinically available $\mathrm{GABA}_{\mathrm{A}}$ receptor agonists, like etomidate and midazolam, might affect stem cell proliferation.

The specific role of each subunit of the $\mathrm{GABA}_{\mathrm{A}}$ receptor in the cell cycle was recently demonstrated in studies on hepatocellular carcinoma cells [24].

Thus, we suppose that cell viability might differ between $\mathrm{AD}$ SCs treated with etomidate and midazolam because both GABAergic agents have different binding affinities on the specific subunit of the $\mathrm{GABA}_{\mathrm{A}}$ receptors $[25,26]$, which determines the potency and efficacy of each agent.

The etomidate binding sites are discovered near the $\alpha 1$ and $\beta_{3}$ subunits of the $\mathrm{GABA}_{\mathrm{A}}$ receptor [27]. Etomidate is highly sensitive to the receptor containing the $\beta_{2}$ or $\beta_{3}$ subunit, but not the $\beta_{1}$ subunit [25]. In animal studies, $\beta_{2}$ and $\beta_{3}$ subunits are shown to play different roles in the anesthetic action of etomidate [28]. The $\beta_{3}$ subunit participates in the loss of consciousness whereas $\beta_{2}$ is involved in the sedative properties of agent.

Midazolam is a kind of benzodiazepine, which produces various actions by binding to its specific site on the $\mathrm{GABA}_{\mathrm{A}}$ receptor that is composed of the respective $\alpha$-subunit ( $\alpha 1, \alpha 2, \alpha 3$, $\alpha 5)$ and the $\gamma 2$-subunit. Each subunit of the benzodiazepine site plays a role in the pharmacologic effects of various agents [29]. The anesthetic action of midazolam is obtunded in the absence of the $\beta_{3}$ subunit [26]. The modulatory effect of midazolam on GABA activated currents via the $\mathrm{GABA}_{\mathrm{A}}$ receptor is negatively influenced by the co-expression of both $\alpha_{6}$ and $\beta_{3}$ subunits [30].

However, our study revealed that the clinically available $\mathrm{GABA}_{\mathrm{A}}$ receptor agonists, etomidate and midazolam, did not modulate the proliferation of stem cells.

However, our study has the limitation that the sample size used was not sufficient to perform parametric statistics. Thus, a further study with a sufficient sample size is needed to confirm the effect of GABAergic anesthetics on ADSC proliferation.

In conclusion, the current study demonstrates that the clinically available GABAergic anesthetics, etomidate and midazolam, did not influence the proliferation ability of ADSCs in control medium. It is also suggested that these anesthetics do not influence the differentiation ability of these cells as observed by the absence of changes in cell proliferation after mixing anesthetics with stem cell differentiation inducers. Additionally, although it is known that etomidate and midazolam have different affinities for the $\mathrm{GABA}_{\mathrm{A}}$ receptor subunits, they showed similar effects on ADSC proliferation both in the control and adipogenic differentiation media.

\section{Acknowledgments}

This study was supported by a grant (No. 2011-0014224) from the National Research Foundation of Korea.

\section{ORCID}

Kyoungho Ryu, http://orcid.org/0000-0002-2886-1836

Dongchan Ko, http://orcid.org/0000-0003-3148-3255

\section{References}

1. Spencer ND, Gimble JM, Lopez MJ. Mesenchymal stromal cells: past, present, and future. Vet Surg 2011; 40: 129-39.

2. Kern S, Eichler H, Stoeve J, Klüter H, Bieback K. Comparative analysis of mesenchymal stem cells from bone marrow, umbilical cord blood, or adipose tissue. Stem Cells 2006; 24: 1294-301.

3. Rigotti G, Marchi A, Galiè M, Baroni G, Benati D, Krampera M, et al. Clinical treatment of radiotherapy tissue damage by lipoaspirate transplant: a healing process mediated by adipose-derived adult stem cells. Plast Reconstr Surg 2007; 119: 1409-22. 
4. Yoshimura K, Sato K, Aoi N, Kurita M, Inoue K, Suga H, et al. Cell-assisted lipotransfer for facial lipoatrophy: efficacy of clinical use of adipose-derived stem cells. Dermatol Surg 2008; 34: 1178-85.

5. Yoshimura K, Sato K, Aoi N, Kurita M, Hirohi T, Harii K. Cell-assisted lipotransfer for cosmetic breast augmentation: supportive use of adipose-derived stem/stromal cells. Aesthetic Plast Surg 2008; 32: 48-55.

6. Sterodimas A, de Faria J, Nicaretta B, Pitanguy I. Tissue engineering with adipose-derived stem cells (ADSCs): current and future applications. J Plast Reconstr Aesthet Surg 2010; 63: 1886-92.

7. Sung PH, Chiang HJ, Chen CH, Chen YL, Huang TH, Zhen YY, et al. Combined therapy with adipose-derived mesenchymal stem cells andciprofloxacin against acute urogenital organ damage in rat sepsis syndromeinduced by intrapelvic injection of cecal bacteria. Stem Cells Transl Med 2016; 5: 782-92.

8. Asano K, Yoshimura S, Nakane A. Adipose tissue-derived mesenchymal stem cells attenuate staphylococcal enterotoxin A-induced toxic shock. Infect Immun 2015; 83: 3490-6.

9. Rodrigues M, Griffith LG, Wells A. Growth factor regulation of proliferation and survival of multipotential stromal cells. Stem Cell Res Ther 2010; $1: 32$.

10. Andäng M, Hjerling-Leffler J, Moliner A, Lundgren TK, Castelo-Branco G, Nanou E, et al. Histone H2AX-dependent GABA(A) receptor regulation of stem cell proliferation. Nature 2008; 451: 460-4.

11. Goffin D, Aarum J, Schroeder JE, Jovanovic JN, Chuang TT. D1-like dopamine receptors regulate GABAA receptor function to modulate hippocampal neural progenitor cell proliferation. J Neurochem 2008; 107: 964-75.

12. Chau PL. New insights into the molecular mechanisms of general anaesthetics. Br J Pharmacol 2010; 161: 288-307.

13. Garcia PS, Kolesky SE, Jenkins A. General anesthetic actions on GABA(A) receptors. Curr Neuropharmacol 2010; 8: 2-9.

14. Zuk PA, Zhu M, Mizuno H, Huang J, Futrell JW, Katz AJ, et al. Multilineage cells from human adipose tissue: implications for cell-based therapies. Tissue Eng 2001; 7: 211-28.

15. Raposio E, Guida C, Baldelli I, Benvenuto F, Curto M, Paleari L, et al. Characterization and induction of human pre-adipocytes. Toxicol In Vitro 2007; 21:330-4.

16. Suva D, Garavaglia G, Menetrey J, Chapuis B, Hoffmeyer P, Bernheim L, et al. Non-hematopoietic human bone marrow contains longlasting, pluripotential mesenchymal stem cells. J Cell Physiol 2004; 198: 110-8.

17. Glass PS, Shafer SL, Reves JG. Intravenous drug delivery systems. In: Miller's Anesthesia. 7th ed. Edited by Miller RD, Eriksson LI, Fleisher LA, Wiener-Kronish JP, Young WL: Philadephia, Churchil livingstone/Elsevier. 2010, p 837.

18. Stowe DF, Bosnjak ZJ, Kampine JP. Comparison of etomidate, ketamine, midazolam, propofol, and thiopental on function and metabolism of isolated hearts. Anesth Analg 1992; 74: 547-58.

19. Fernando RN, Eleuteri B, Abdelhady S, Nussenzweig A, Andäng M, Ernfors P. Cell cycle restriction by histone H2AX limits proliferation of adult neural stem cells. Proc Natl Acad Sci U S A 2011; 108: 5837-42.

20. Greco SJ, Zhou C, Ye JH, Rameshwar P. A method to generate human mesenchymal stem cell-derived neurons which express and are excited by multiple neurotransmitters. Biol Proced Online 2008; 10: 90-101.

21. Anghileri E, Marconi S, Pignatelli A, Cifelli P, Galié M, Sbarbati A, et al. Neuronal differentiation potential of human adipose-derived mesenchymal stem cells. Stem Cells Dev 2008; 17: 909-16.

22. Fiszman ML, Borodinsky LN, Neale JH. GABA induces proliferation of immature cerebellar granule cells grown in vitro. Brain Res Dev Brain Res 1999; 115: 1-8.

23. LoTurco JJ, Owens DF, Heath MJ, Davis MB, Kriegstein AR. GABA and glutamate depolarize cortical progenitor cells and inhibit DNA synthesis. Neuron 1995; 15: 1287-98.

24. Liu Y, Li YH, Guo FJ, Wang JJ, Sun RL, Hu JY, et al. Gamma-aminobutyric acid promotes human hepatocellular carcinoma growth through overexpressed gamma-aminobutyric acid A receptor alpha 3 subunit. World J Gastroenterol 2008; 14: 7175-82.

25. Sanna E, Murgia A, Casula A, Biggio G. Differential subunit dependence of the actions of the general anesthetics alphaxalone and etomidate at gamma-aminobutyric acid type A receptors expressed in Xenopus laevis oocytes. Mol Pharmacol 1997; 51: 484-90.

26. Quinlan JJ, Homanics GE, Firestone LL. Anesthesia sensitivity in mice that lack the beta3 subunit of the gamma-aminobutyric acid type A receptor. Anesthesiology 1998; 88: 775-80.

27. Li GD, Chiara DC, Sawyer GW, Husain SS, Olsen RW, Cohen JB. Identification of a GABAA receptor anesthetic binding site at subunit interfaces by photolabeling with an etomidate analog. J Neurosci 2006; 26: 11599-605.

28. Reynolds DS, Rosahl TW, Cirone J, O'Meara GF, Haythornthwaite A, Newman RJ, et al. Sedation and anesthesia mediated by distinct GABA(A) receptor isoforms. J Neurosci 2003; 23: 8608-17.

29. Möhler H, Fritschy JM, Rudolph U. A new benzodiazepine pharmacology. J Pharmacol Exp Ther 2002; 300: 2-8.

30. Alsbo CW, Kristiansen U, Møller F, Hansen SL, Johansen FF. GABAA receptor subunit interactions important for benzodiazepine and zinc modulation: a patch-clamp and single cell RT-PCR study. Eur J Neurosci 2001; 13: 1673-82. 